\title{
A historical analysis of the economic marginalisation of Aboriginal people and the ruralisation of Aboriginal issues
}

\author{
Matthew Byers
}

\begin{abstract}
This essay examines the complex geographical, economic and political motivations that have resulted in the framing of Aboriginal participation in Australia as a predominantly rural issue.
\end{abstract}

Keywords: Aboriginal history; Indigenous economic participation; ruralisation

Ever since the establishment of the Australian colonial nation, Aboriginal people have been marginalised and exploited in the interest of economic advancement. The dispossession that fed the Australian pastoral economy established the conditions that led to the framing of Aboriginal participation as a predominately rural issue. This rural focus is at the heart of the policies of child removal of the 19th and 20th century, it is imbued in the debate surrounding land rights and Native Title, and has been revived in contemporary initiatives such 'Closing the Gap' and the Indigenous Protected Area system. In this essay, I will examine the impact and legacy of these significant government actions, and trace the way complex geographical, economic, and political motivations sustained the rural focus in the area of Aboriginal economic participation.

To understand the current economic status of Indigenous Australians, it is necessary to recognise the lasting impact of early colonial activities. These activities - founded on the racist assumption of Australia as an empty land - led to the total economic marginalisation of Aboriginal people. As Hulme explains, colonial societies are defined by their intention to either establish trade or to establish a settlement (cited in Gillen \& Ghosh 2007). When a colony was established in NSW in 1788, British colonisers saw no potential to establish trade with what they saw as an inferior "dying race" Gillen \& Ghosh 2007, p. 164). As such, colonial powers focused on "expropriating Aboriginal land" to supplement the creation of extensive pastoral and resource industries (Morris 1989, p. 7). The massacre and marginalisation that facilitated this expropriation was exacerbated by the colonial dependence on convicts, rather than slaves, as a labour force, which meant that Aboriginal people continued to be peripheralised even as "roughly half" of NSW was excised for pastoral use by 1845 ((Morris 1989, p. 10). As isolated attempts to incorporate Aboriginal people into the labour force 
failed and frontier violence escalated, settler societies began to frame Aboriginal people as "ignoble savages" defined by their inherent "treachery" (Morris 1992, pp. 82). This racist conception of Aboriginal people as "obstacles to rather than resources for colonial exploitation" (Morris 1989, p. 11) ensured their structural marginalisation that underpinned the rural focus in Aboriginal economic issues in the following centuries.

Over the course of the formative centuries of Australian colonialism, Aboriginal people slowly began to be absorbed into the labour force. However, Aboriginal people were typically limited to occupying unpaid subservient roles that validated racist conceptions of inferiority. Martinez and Lowrie reveal the way Aboriginal people in the Northern Territory in the early 20th century were "officially endorsed as an exception to the white labour policy" to fill the demand for domestic servants - an industry in which white labour was scarce (2009, p. 309). Upon realising the potential for Aboriginal people to serve as cheap household labour, white governments of the time looked to ensure the supply of Aboriginal servants by implementing policies of child removal (Swan 1988). By focusing on the removal of children - particularly Aboriginal children of "mixed descent" (Attwood \& Magowan 2001, p. 184) - governments could ensure a reasonable utilisation of Aboriginal labour whilst structurally facilitating the death of what they saw as an inferior dying race. In 1909, NSW politician Robert Donaldson asserted that the fate of Aboriginal adults was an unavoidable and early death, and that the only hope for Aboriginal children was "complete isolation from the camps and stations" which happened to be located on the remote lands onto which Aboriginal people had been pushed by colonial expansion (cited in Read 2002). Donaldson justified the urgency of the situation by explaining that of "3,200 [Aboriginal] children...threefourths...range from half-castes to almost white", and therefore possessed and inherent capacity to be saved from a "useless life of idleness" by being assimilated into white society (Read 2002, p. $55)$.

It is important to recognise this racial imperative, because it illustrates that the motivations behind the policies of child removal were not solely economic. In 1939, as Aboriginal children continued to be taken from their communities, the Secretary of the Australian Aborigines' League William Cooper posited the notion of employing Aboriginal people in the development of Australia's remote regions. He saw such an arrangement as having the potential to redefine "the Aboriginal as [an] asset and not a liability", and even professed his support for "white guidance" to gain approval for his proposal (McGregor 2011, p. 42-43). However, the reason why - in Cooper's own words - "it never occurred to the white minds to link the Aboriginal problem... with the problem of the empty spaces" (ibid, p. 41), was that recognising this potential would undermine the view of Aboriginal people as an 'idle' and dying race which was held up as the justification for the policies of removal. Ultimately, the economic capacity of Aboriginal people in this era was restricted by the genocidal aims of government (Attwood \& Magowan 2001).

This racist view of Aboriginal people limited their capacity for economic participation up until and during the 1970s, 80s and 90s when debates around land rights and Native Title began to emerge. While Aboriginal people viewed land rights as a key factor in ensuring economic independence and social change, rural governments saw land rights as an indiscriminate land grab that would threaten the livelihoods of farmers, and blamed "the poor attitude of the Aborigines to education, [and] employment" as the root cause of their economic disadvantage (Norman 2015, p. 10). Another 
industry that shared these sentiments was the mining industry, which - with the help of state governments - consistently dismissed calls for negotiation and forcibly removed Aboriginal people from their lands to allow mining operations to proceed unimpeded (Langton 2013a). However, as mining companies faced widespread backlash and state and federal governments felt the political sting of the land rights movement, the view of Aboriginal people as 'obstacles' to growth began to shift. Upon engaging with the concerns of Aboriginal people, mining companies quickly found that Aboriginal people did not reject the possibility of mining in general, "but were concerned about the racist and inequitable situation of the past being replicated...in new ventures" (Langton 2013a, p. 18/20). This shift was catalysed by the introduction of the Aboriginal Land Rights Act in 1976, and the Native Title Act in 1993, which reframed Aboriginal people as potential partners and beneficiaries, rather than obstacles to growth.

With state and federal legislation granting Aboriginal people "a seat at the table", many successful settlements were negotiated, with the best of these ensuring "several billions of dollars for future generations, along with jobs and enterprise development" (Langton 2013a, p. 19/20). One such example was the Argyle Diamonds Indigenous Land Use Agreement 2005, which was a Native Title agreement over mining operations in the Kimberley in Western Australia between the traditional Aboriginal custodians and Rio Tinto ltd. The agreement resulted in an Aboriginal employment rate of $25 \%$ at the mine itself, and helped dispel prevailing racist stereotypes in the surrounding outposts and communities (Langton 2013a, p. 5/20). Native Title agreements such as this placed Indigenous people in a good position to take advantage of the mining boom, with the number of Indigenous people employed in the mining industry doubling to over 7,000 between 2006 and 2011 (Hunter et al. 2015). However, the benefits of Native Title have been neither permanent nor universal. With the slow collapse of the mining boom from 2011 onwards, many of the rural mining jobs occupied by Aboriginal people were lost and surrounding Aboriginal enterprises suffered (Lateline 2015).

Another important factor determining the equity of Native Title Agreements is the attitude of companies to their "corporate social responsibility" (ibid, p. 2). Rio Tinto, for example - who negotiated the Argyle mine agreement and employ roughly 1,500 Indigenous people across Australia - have mainly been driven by internal policy rather than any binding legal framework. In fact, Rio Tinto's policy of respecting Native Title and working constructively with Indigenous populations was met with fierce opposition by others in the mining industry when it was originally proposed in 1995 (Langton 2013b). While initiatives such as these have become necessary in maintaining a company's social "license to operate" (O'Faircheallaigh 2006, p. 6), many companies offer little more than what is legally required in the way of environmental or cultural management and are more concerned with ensuring profitability (O'Faircheallaigh 2006, p. 17).

Further to the detriment of Native Title, neoliberal governments from the 1990s onwards began to wind back its to ensure the economic security of the mining industry. Examples of this included the 10-point plan amendment made by the Howard government in 1998, which "substantially weakened the position of native title claimants" and forced Aboriginal people to agree to terms they might otherwise have opposed (O'Faircheallaigh, p. 10). However, the most significant shortcoming of Native Title is the fact that it limits land claims to land that is not already privately owned (New South Wales Aboriginal Land Council 2017). As such, a majority of successful Native Title claims have been in central, northern, and western Australia, while less than $3 \%$ of NSW has been returned 
under Native Title (National Native Title Tribunal 2017). Not only does this restrict Native Title claims to land that has been deemed economically unviable by white settlers, but it structurally ensures the limitation of land claims to rural areas, thereby reinforcing the conception of Aboriginal economic participation as a rural issue.

A similar reaffirmation of Aboriginal economic participation as a rural issue can be seen in the Rudd government's 2009 'Closing the Gap' initiative. As Altman reveals, this initiative placed a heavy focus on rural communities and obstinately defined the issue as that of an uneducated and geographically isolated labour force for whom the only solution was economic assimilation (Altman 2010). The program abolished many community-supported employment initiatives in favour of employment in mainstream industries such as mining and resources, and encouraged Aboriginal people to move off their land to less remote locations to find work (ibid, p. 260). Altman views the 'Closing the Gap' initiative as a neoliberal "authoritarian moralism" (Altman 2010, p. 266) which assumes that any advancement for Aboriginal people is contingent on "a full embrace of the market economy" and the absorption of traditional "kin-based societies...[into] market-based individualistic societies" (Altman 2010, p. 268).

However, Altman's critique may be revelatory of another more contemporary ruralisation of the Aboriginal economic problem by what Langton describes as "wilderness campaigners", who "need Aboriginal people to be powerless victims in their allegorical drama of capitalism in order for their own agendas to make sense" (2013d, 5/13). Indigenous leaders such as Langton and Pearson (2014) reject this view of Aboriginal people and see it as affecting the same kind of economic exclusion as the overtly neoliberal initiatives these campaigners are directly trying to oppose. What this conflict of ideology reveals is that regardless of whether Aboriginal people are being stereotyped into the mould of the "new noble savage" (Langton 2013a, p. 1/20) or are being subjected to the familiar government commitment "to sedentarise, civilise...[and] 'develop' Aboriginal people" (Langton 2013a, p. 277), Aboriginal people are refused agency over defining their own economic futures.

Despite these ideological shortcomings, Altman's critique of 'Closing the Gap' is substantiated by the fact that no significant progress has been made on most of the policy's core goals, including and especially the gap in Indigenous employment which has increased since 2008 (Conifer et al. 2017). Even Pearson - who is a strong advocate of economic integration - rejects the idea of 'closing the gap' as an oversimplification predicated on the assumption that it is Indigenous people who must move towards change, even if this means sacrificing their own unique cultural heritage (2014).

However, despite the shortcomings of the 'Closing the Gap' initiative, there are some examples of rural policy initiatives that recognise and value the cultural capital of remote Indigenous people. The Indigenous Protected Areas (IPA) scheme, introduced in 1996, has allowed Indigenous custodians to remain on country performing services that ensure the environmental and cultural wellbeing of remote Australia such as "tourism management...feral animal management and land rehabilitation” (Langton 2013c, p. 15/22). These IPA's have also placed Indigenous people on the frontier of the 'green economy'. On the Warddeken IPA in West Arnhem land, traditional owners have partnered with a natural gas company to implement a carbon abatement scheme that generates $\$ 4$ million a year for the local Aboriginal community (Social Ventures Australia 2016, p. 16). There 
are currently 75 IPA's covering more than 67 million hectares and employing more than 500 Indigenous people (Department of the Prime Minister and Cabinet 2017).

Despite this, IPA's are not an assured path to economic independence and self-determination, as they are largely dependent government funding and are therefore subject to the whims of political change (Ross et al. 2009, p. 247). While providing a way of rewarding knowledge, culture and customs that are not rewarded by the market, IPA's represent what Pearson describes as "the lesser idea of self-management, whereby the indigenes are given management functions in policies that are determined by government" (2014, p. 46). IPA rangers also face backlash from "wilderness campaigners' when they establish projects that conflict with their environmental imperatives (Langton 2013c). However, the respect for cultural knowledge at the heart of this policy is a marked deviation from the neo-assimilationist impetus hidden under the surface of the 'Closing the Gap' initiative. While IPA's may confine Indigenous people to a position of self-management, they still offer a level of existential freedom that does not demand moving off country to find commonplace work. The ideological divergence of these policies is indicative of the complexity of contemporary Aboriginal economic participation. A further indication of this complexity is the fact that the IPA system and the benefits its presents have been conglomerated as part of the 'Closing the Gap' scheme. It is this sort of complexity and contradiction of purpose that muddies the perception of Aboriginal economic participation in Australia.

The consistent ruralisation of Aboriginal economic issues is an act of cognitive distancing that tries to absolve governments and settler society from their own responsibility in ensuring this rural marginalisation. Understanding that the ruralisation of Aboriginal economic problems was founded upon the dispossession of land, exacerbated by marginalisation of Aboriginal people, sustained as a justification for racial assimilation, and revived to serve contemporary economic interests will be imperative if governments are to understand the breadth of their responsibility. If governments insist on perpetuating this view without an understanding of the colonial processes and subsequent government interventions that facilitated it, they will be sure to repeat the mistakes of the past.

\section{References}

Altman, J. 2010, 'What future for remote Indigenous Australia? Economic hybridity and the neoliberal turn', Culture crisis: Anthropology and politics in Aboriginal Australia, pp.259-280.

Attwood, B. and Magowan, F. 2001, 'Learning about the truth' The stolen generations narrative', in Telling stories, 1st edn, Allen \& Unwin, Crows Nest, N.S.W, pp. 183-212.

Conifer, D., Leslie, T., Tilley, C. and Liddy, M. 2017, Australia is failing to close the gap on Indigenous disadvantage, viewed 3 June 2017, http://www.abc.net.au/news/2017-02-14/closing-thegap-report-card-failing/8268450.

Department of the Prime Minister and Cabinet 2017, Indigenous Protected Areas - IPAs |

Department of the Prime Minister and Cabinet, viewed 3 June 2017, http://www.dpmc.gov.au/indigenous-affairs/environment/indigenous-protected-areas-ipas. 
Gillen, P. and Ghosh, D. 2007, 'Race', in Colonialism and modernity, 1st edn, Univ. of New South Wales Press, Sydney, pp. 156-177.

Hunter, B., Howlett, M. and Gray, M. 2015, The Economic Impact of the Mining Boom on Indigenous and Non-Indigenous Australians, Asia \& the Pacific Policy Studies, vol 2, no 3, pp.517530, viewed 25 May 2017,

http://caepr.anu.edu.au/sites/default/files/Publications/WP/WP93_Hunter_Howlett_Gray_Mining.p df.

Langton, M. 2013a, 'Faustian Bargain or survival strategy? Mining and Aboriginal economic empowerment', in Boyer lectures 2012. The Quiet Revolution., Kobo desktop book, ABC Books, Sydney.

Langton, M. 2013b, 'Legacies , New Partnerships and Plans: How Traditional Owners can Settle their Grievances with the Old Mining Culture', in Boyer lectures 2012. The Quiet Revolution., Kobo desktop book, ABC Books, Sydney.

Langton, M. 2013c, 'The First Australian's Gift to the World: 30 Million Hectares of Protected Areas to Conserve Environments and Biodiversity', in Boyer lectures 2012. The Quiet Revolution., Kobo desktop book, ABC Books, Sydney.

Langton, M. 2013d, 'Introduction', in Boyer lectures 2012. The Quiet Revolution., Kobo desktop book, ABC Books, Sydney.

Lateline 2015, End of the mining boom leaves economic impact on Indigenous people in rural Australia, television program, ABC TV, Sydney, July 31, viewed 25 May 2017, http://www.abc.net.au/lateline/content/2015/s4284993.htm.

Martínez, J. and Lowrie, C. 2009, Colonial Constructions of Masculinity: Transforming Aboriginal Australian Men into 'Houseboys', Gender \& History, vol 21, no 2, pp.305-323, https://doi.org/10.1111/j.1468-0424.2009.01550.x.

McGregor, R. 2011, 'Aboriginal activists demands acceptance', in Indifferent inclusion, 1st edn, Aboriginal Studies Press, Canberra, pp. 37-54.

Morris, B. 1992, Frontier colonialism as a culture of terror, Journal of Australian Studies, vol 16, no 35, pp.72-87, https://doi.org/10.1080/14443059209387119.

Morris, B. 1989, 'Chapter 1: Colonial Domination as a process of Marginalisation', in Domesticating resistance, 1st edn, Berg, Oxford, pp. 7-30.

National Native Title Tribunal 2017, 'Native Title Determinations', 31 March, viewed 9 June, http://www.nntt.gov.au/Maps/Determinations_map.pdf.

New South Wales Aboriginal Land Council 2017, Comparison of Land Rights and Native Title in NSW, viewed 9 June, http://www.alc.org.au/publications/fact-sheets.aspx.

Norman, H. 2015, 'Government, Aborigines and Power: the 1978 Land Rights Inquiry', in What do we want?', 1st edn, ACT Aboriginal Studies Press, Canberra. 
O'Faircheallaigh, C. 2006, Aborigines, mining companies and the state in contemporary Australia: A new political economy or 'business as usual'?, Australian Journal of Political Science, vol 41, no 1, pp.1-22, https://doi.org/10.1080/10361140500507252.

Pearson, N., 2014, A rightful place: Race, recognition and a more complete Commonwealth, Quarterly Essay, (55), p.1.

Read, P. 2002, Clio or Janus? Historians and the stolen generations, Australian Historical Studies, vol 33, no 118, pp.54-60, https://doi.org/10.1080/10314610208596179.

Ross, H., Grant, C., Robinson, C., Izurieta, A., Smyth, D. and Rist, P. 2009, Co-management and Indigenous protected areas in Australia: achievements and ways forward, Australasian Journal of Environmental Management, vol 16, no 4, pp.242-252,

https://doi.org/10.1080/14486563.2009.10648783.

Social Ventures Australia 2016, 'Consolidated report on Indigenous Protected Areas following Social Return on Investment analyses', February 2016, Department of the Prime Minister and Cabinet, Canberra, pp. 1-30.

Swan, p. 1988, 200 years of unfinished business, Aboriginal and Islander Health Worker Journal, vol 12, no 4, pp. 29-40.

(C) 2018 by the author. This article is distributed under the terms and conditions of the Creative Commons Attribution license (http://creativecommons.org/licenses/by-nd/4.0/). 